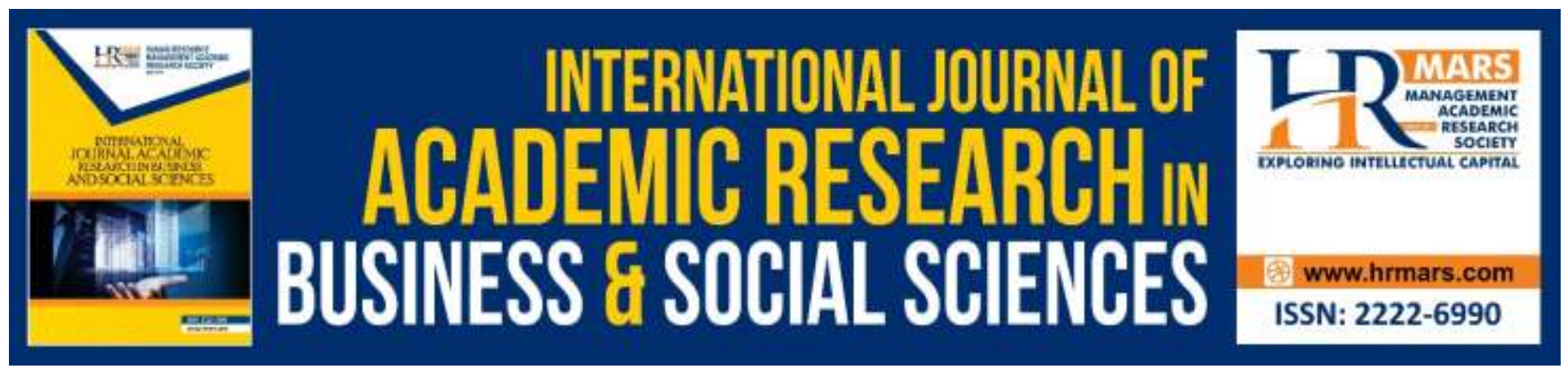

\title{
Common Mistakes in Primary Year 6 English as Second Language (ESL) Pupils' Sentence Construction Using Word- Phrase-Sentence (WPS) Pyramid Strategy
}

Cherryl Chandat Anak John Linggir, Hamidah Yamat

To Link this Article: http://dx.doi.org/10.6007/IJARBSS/v10-i2/6960

DOI:10.6007/IJARBSS/v10-i2/6960

Received: 21 January 2020, Revised: 08 February 2020, Accepted: 17 February 2020

Published Online: 29 February 2020

In-Text Citation: (Linggir \& Yamat, 2020)

To Cite this Article: Linggir, C. C. A. J., \& Yamat, H. (2020). Common Mistakes in Primary Year 6 English as Second Language (ESL) Pupils' Sentence Construction Using Word-Phrase-Sentence (WPS) Pyramid Strategy. International Journal of Academic Research in Business and Social Sciences, 10(2), 708-721.

Copyright: (C) 2020 The Author(s)

Published by Human Resource Management Academic Research Society (www.hrmars.com)

This article is published under the Creative Commons Attribution (CC BY 4.0) license. Anyone may reproduce, distribute, translate and create derivative works of this article (for both commercial and non-commercial purposes), subject to full attribution to the original publication and authors. The full terms of this license may be seen

at: http://creativecommons.org/licences/by/4.0/legalcode

Vol. 10, No. 2, 2020, Pg. 708 - 721

http://hrmars.com/index.php/pages/detail/IJARBSS

JOURNAL HOMEPAGE

Full Terms \& Conditions of access and use can be found at http://hrmars.com/index.php/pages/detail/publication-ethics 


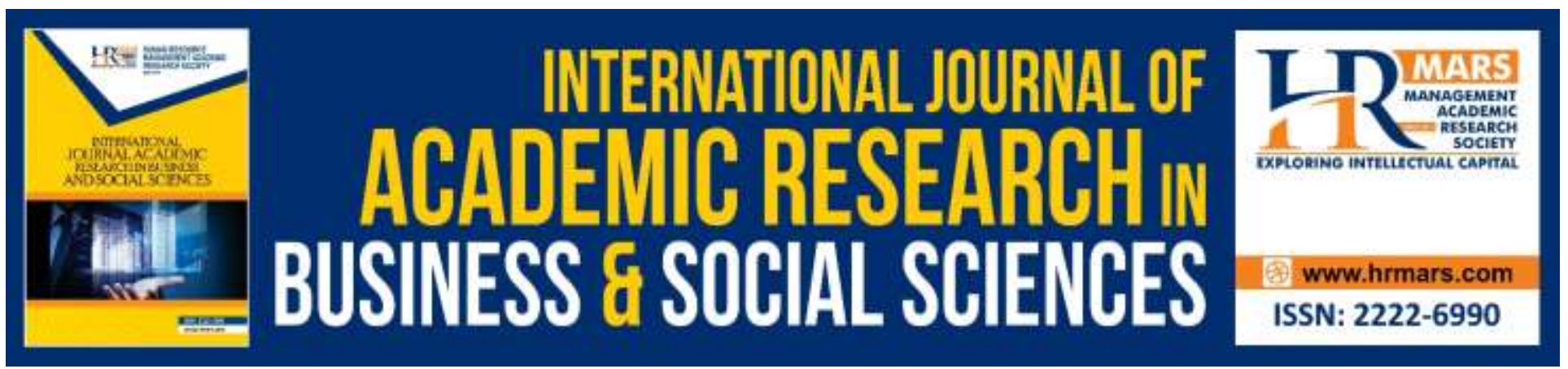

\title{
Common Mistakes in Primary Year 6 English as Second Language (ESL) Pupils' Sentence Construction Using Word-Phrase-Sentence (WPS) Pyramid Strategy
}

\author{
Cherryl Chandat Anak John Linggir, Hamidah Yamat \\ Universiti Kebangsaan Malaysia, Bangi
}

\begin{abstract}
Writing has been one of the difficult learning skills to be learnt in the English as Second Language (ESL) classrooms in Malaysia. Pupils in the sub-urban or rural areas tend to make some major mistakes in sentence construction due to the lack of exposure towards English Language as well as lack of interest and motivation in learning the language. This paper aimed to discuss on the common mistakes made by the ESL learners in their English Language writing specifically on their sentence construction. Pre and post-tests had been given to the participants of Primary 6 ESL pupils in one of the primary schools in Saratok, Sarawak. The pre and post tests were given before and after the teaching of sentence construction using Word-Phrase-Sentence (WPS) Pyramid strategy. The research had unveiled that the WPS Pyramid strategy had helped the pupils to improve their sentence construction ability in the ESL writing. The research is suggested to assist English Language teachers, ESL students and teacher trainees in the learning and teaching of English Language.

Keywords: Writing, Common Mistakes, Primary ESL Classroom, Sentence Construction, WPS Pyramid
\end{abstract}

\section{Introduction}

In accordance to the Curriculum Content of the English Language teaching and learning, Level 2 pupils (Year 4 - Year 6) are expected to write their ideas clearly in writing and with the teacher's guidance, it enables the pupils to develop themselves in becoming independent writers (KPM, 2015). However, it is always difficult to find pupils writing their essays with very few grammatical errors (Marlyna, Tan \& Khazriyati, 2007). Teachers teaching the English Language have to come out with suitable writing strategy which not only caters to the pupils need in improving their writing skill but also captures their interest and motivation in learning the language.

English Language in Malaysia has been made as one of the compulsory subjects to be learnt in all education levels especially in primary and secondary schools. In fact, in primary school levels, the pupils are required to learn the language for 6 years, starting from Year 1 to Year 6 , with the pupils 
INTERNATIONAL JOURNAL OF ACADEMIC RESEARCH IN BUSINESS AND SOCIAL SCIENCES Vol. 10, No. 2, Feb, 2020, E-ISSN: 2222-6990 @ 2020 HRMARS

aged 7 years old to 12 years old. As English is learnt as the second language in the country, it has made the language as the second most important and commonly used language among big number of Malaysians.

There are 4 main skills in the English Language namely listening, speaking, reading and writing. Among all, writing skill has been the most difficult skill to be learnt and acquired by the Malaysian pupils as second language learners (Nooreiny, Hamidah \& Kee, 2011). The pupils have lack of confidence towards their writing ability and it causes them to be reluctant to perform well in their writing tasks (Ahn, 2012). In the Malaysian primary school, Ujian Penilaian Sekolah Rendah (UPSR) involves mostly writing skill especially in Writing Paper 2, Section B and C. Section B carries 12 marks for Question B ii and Section C carries 25 marks which make out 37 marks out of 50 marks. It means that the writing parts carry more than half of the total marks and it need the pupils to write and construct sentences well in order for them to get good marks or at least get passing marks for Paper 2.

Malaysia with its multiracial status is occupied with citizens of different ethnicity, background and social status. Hence, English Language, though it is formally known as the second language in the country, it is somewhat considered as the third or fourth language among some of the Malaysians. This situation is due to the lack of exposure of the English Language usage in their daily lives especially those living in the sub-urban or the rural parts in the country. In these areas, the people are more comfortable conversing in their mother tongue in all their activities. According to llyana et. al. (2015), this situation leads to the English Language being viewed as not important for their immediate need without realizing its benefit towards their future undertaking. Pupils in the rural areas generally view the language as difficult and this could hinder them to be motivated and interested in learning it. The pupils will not use English Language into practise outside the classroom environment as they find it difficult and they somehow only thought of the language as one of the subjects they needed to learn in school. As this situation takes place, it is undoubtedly unable the pupils to sustain or maintain their English Language acquisition or learning towards betterment.

Writing strategy as accordance to Silva (2014) is a conscious mind activity with the aim to solve problems in writing within a learning environment. Therefore, this study introduces a writing strategy called Word-Phrase-Sentence (WPS) Pyramid to cater the needs of the Primary Year 6 English as Second Language (ESL) learners in one of the sub-urban schools in Saratok, Sarawak to construct better sentences due to their writing difficulties mentioned above. WPS Pyramid is performed by expanding a word into a phrase and lastly into a sentence in a form of a pyramid in which the pupils will be able to see their sentence construction expanding.

This study was conducted with the aim to determine the type of common mistakes made by the Primary Year 6 ESL pupils in sentence construction. Hence, the objective is as below:

- To determine the type of common mistakes made by the Primary Year 6 ESL pupils in sentence construction.

This study is to be carried out based on the following research question:

- What are the type of common mistakes made by the Primary Year 6 ESL pupils in sentence construction? 
INTERNATIONAL JOURNAL OF ACADEMIC RESEARCH IN BUSINESS AND SOCIAL SCIENCES Vol. 10, No. 2, Feb, 2020, E-ISSN: 2222-6990 @ 2020 HRMARS

This study is hoped to cater the needs of the English Language teachers, especially those teaching in the sub-urban and rural primary schools with low performance ESL pupils as well as a guidance to improve the teaching and learning capabilities among English Language teacher trainees in Institut Pendidikan Guru (IPG) in the country.

\section{Literature Review}

Several past studies had identified some common mistakes in the ESL sentence constructions among primary school pupils. Among all, in a study conducted by Muhammad Noor and Nurahimah (2015), they stated that the Primary Year 4 ESL pupils in a rural school had difficulty in terms of spelling, stringing words into sentences and had a tendency to include Bahasa Melayu words into their writing. Also, the pupils made major grammatical errors in their writing tasks. These were due to the limited access to the English Language as accordance to the researchers. We can observe that these pupils were more comfortable in using Bahasa Melayu as they included the language in their English Language writing though it is a major mistakes in the ESL writing. Meanwhile, Arshad and Hawanum (2017) had conducted a study to solve pupils' problem in using the English auxiliary 'be'. They viewed this sentence construction problem as one of the major concerns that needed to be solved in order to help the Primary Year 5 ESL pupils in their study. The researchers in this study stated that the auxiliary 'be' is a common grammatical form used in the English Language but the pupils were unable to use it correctly as in there are no similar form in Bahasa Melayu. Melor, Tan and Muhammad Asyraf (2019) informed that the Primary Year 6 ESL pupils in their study had difficulties in writing sentences with correct grammar. This was due to their lack of awareness towards their sentence construction as well as because English Language was not their first language. Hence, they were unable to see their mistakes well. Dg Nursazwani, Wardatul and Asmaa (2018) observed that the Primary Year 5 ESL pupils in a rural school where they conducted their study were lacking of vocabulary acquisition. In addition, they stated that the pupils were unable to express their ideas clearly using the correct choice of words. In other words, by having the lack of the English Language vocabulary knowledge, pupils were unable to write their ideas or thoughts into words successfully and coherently though the ideas could be good and were thought creatively and critically in the first place.

There had been a numerous past studies conducted in developing or improving pupils' ability to construct better sentences. In a study conducted by the above mentioned researchers, Melor, Tan and Muhammad Asyraf had implemented Instawrite in which the pupils used Instagram daily. The pupils were given a picture and they were required to write a paragraph based on the picture given and these were done every day in order for them to be able to construct sentences better after being given the feedback. This resulted in the pupils to be able to improve their writing as well as adhere to the correct use of Subject-Verb-Agreement (SVA). In another study conducted by Jashil, EsteeLaura and Melor (2019), they implemented a sentence construction strategy called the "Rainbow Tower" to improve pupils' ability in constructing present continuous sentences. The pupils in their study were needed to sequence different parts of speech which were represented by different colours in constructing present continuous sentences correctly. This colour-coding strategy resulted in a significant improvement among the pupils in constructing better present continuous sentences. Dg Nursazwani, Wardatul and Asmaa in their study had conducted a sentence construction strategy which focused more towards solving pupils' vocabulary acquisition. As mentioned before, vocabulary 
acquisition was viewed as the major concern in sentence construction among the pupils as vocabulary is closely related in expressing ideas using correct choice of words. They introduced the Vocabulary Acquisition, Application, Writing (VAW) method where the pupils were introduced to new vocabularies and they would undergo drilling practices using the VAW method. This strategy expected to develop pupils' sentence construction through vocabulary enhancement.

\section{Theories Related}

John Dewey's Constructivism Theory suggests that having the same amount of delivering knowledge and considering upon the interest and the experience is the idea towards learning (Rudd, 2019). Also, the pupils are given the ownership in acquiring their learning and at the same time being the problemsolver on their own (Pragasam et. al., 2018). This theory suits the WPS Pyramid strategy implemented in this study as the ESL pupils were taught to be responsible on their own ability to construct sentences using their own knowledge and ideas. Meanwhile, Howard Gardner's Multiple Intelligences believes that there are equal opportunities for the pupils to maximise their multiple intelligences (Faidah, Fauzati \& Suparno, 2019). Gardner and Hatch (1989) defined pupils with linguistic intelligence are able to adhere to the meaning of words and the function of the language. This study focuses on sentence construction with the pupils expanding a word into a phrase and lastly into a sentence. The sentence construction were also performed in a form of a pyramid so it would be easier for the pupils to see clearly on how their sentence can be constructed.

\section{Methodology}

The research was carried out in a low-enrolment sub-urban school in Saratok, Sarawak to a group of 6 Primary Year 6 pupils aged 12 years old. The pupils were selected as the participants based on convenience sampling of non-probability or non-random sampling. Convenience sampling can be referred as Haphazard Sampling in which the participants of a research adhere to a certain criteria such as accessibility, geographical proximity, availability of an allocated time and the willingness to participate in the research (Etikan, Sulaiman \& Rukayya, 2016). The pupils in this study performed poorly by achieving $C$ or $D$ in their school tests. This is caused by the perception of the pupils in which they view English Language as a tough or difficult subject to be learnt and acquired as compared to Bahasa Malaysia. This resulted in them on not performing the language as much as possible or in other words, not practising the language especially when they are out of the classroom environment. This study was conducted by applying a qualitative document analysis research using thematic analysis approach. According to Bowen (2009), a document analysis research is a research where the researcher reviews or evaluates document. Thematic analysis approach refers to the method of identifying, analysing and reporting the themes or patterns found in the document (Braun \& Clarke, 2006; Bree \& Gallagher, 2016). In performing the thematic analysis approach, there are 6 phases that need to be done (Braun \& Clarke, 2006). The six phases are simplified as follows: 
INTERNATIONAL JOURNAL OF ACADEMIC RESEARCH IN BUSINESS AND SOCIAL SCIENCES Vol. 10, No. 2, Feb, 2020, E-ISSN: 2222-6990 @ 2020 HRMARS

Table 1.0 Thematic Analysis

\begin{tabular}{ll}
\multicolumn{1}{c}{ Phase } & \multicolumn{1}{c}{ Description } \\
\hline 1 - Familiarization of data & $\begin{array}{l}\text { Reading and re-reading the transcripts } \\
\text { Organising data by coding } \\
\text { - Generating initial codes } \\
3 \text { - Searching of theme }\end{array}$ \\
& $\begin{array}{l}\text { Examining the codes and fitting it into } \\
\text { themes } \\
\text { Reviewing, modifying and developing the } \\
\text { themes }\end{array}$ \\
5 - Reviewing themes & $\begin{array}{l}\text { Refining the themes } \\
\text { Writing the report }\end{array}$ \\
\hline
\end{tabular}

Hence, it suits this study as this study aims to determine the type of common mistakes made by the Primary Year 6 pupils in their sentence construction. According to Hinkel (2010), there are 10 common mistakes in the second language writing which the ESL pupils always perform. These common mistakes were applied as guidance in determining the themes representing the common mistakes found in the implementation of this study. The common mistakes are stated as follows:

Table 2.0 Common mistakes made by ESL pupils

in ESL sentence construction (Hinkel 2010)

- Sentence division, fragmented and clipped sentences and run-ons
- Subject-verb-agreement
$\bullet$ Verb tenses and aspects, verb phrases
$\bullet$ Incorrect word forms
$\bullet$ Incomplete or incorrect subordinate clause structure
$\bullet$ Singular and plural nouns and pronouns
$\bullet$ Missing or incorrect prepositions
$\bullet$ Missing or incorrect articles
$\bullet$ Incorrect modal verbs

\section{Research Procedures}

Pre and post-writing tasks were conducted in order to gain data for this study. The pre-writing task was given before the implementation of the WPS Pyramid strategy while the post-writing task was given after the implementation of the WPS Pyramid strategy. The question provided in both pre and post-writing tasks was the same. It was done in order to differentiate the common mistakes made by the pupils in their English Language sentence construction. The questions given were based on the essay type question which were tested in the UPSR Paper 2 Writing for Section C. The pupils were required to construct sentences using the list of words based on the situation given. WPS Pyramid strategy is introduced to help the ESL pupils in constructing better sentences and its functions are stated as below: 


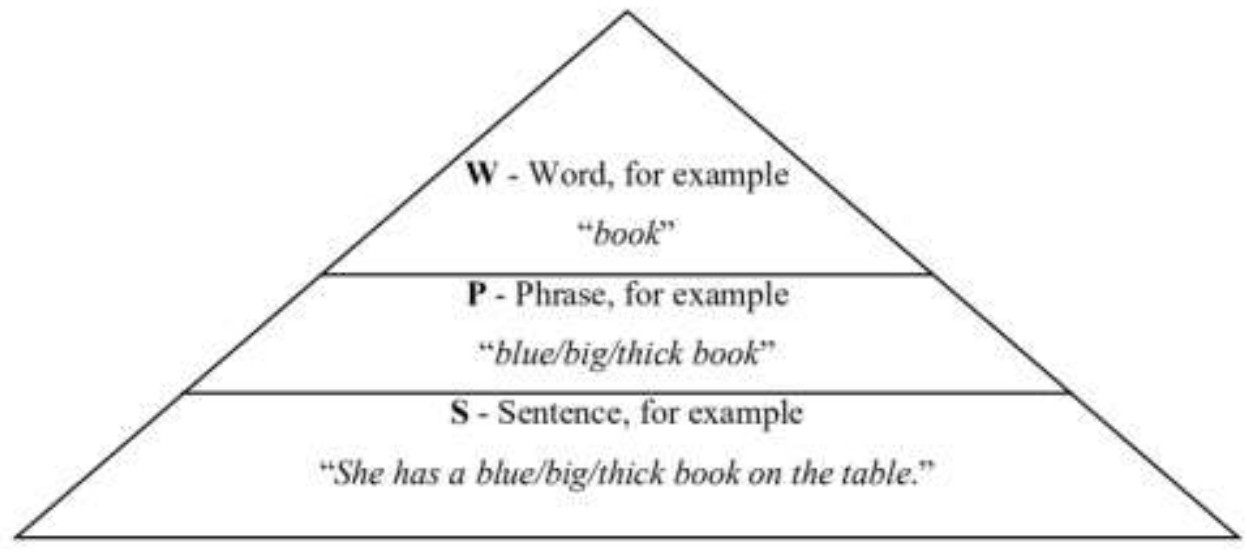

Figure 1.0 The use of WPS Pyramid

\section{Data Analysis}

The pupils' writing product from the pre and post-writing tasks were collected. It was then analysed based on Thematic Analysis approach as mentioned before. The comparison and the differentiation of the writing product was made in order to determine the common mistakes made by the pupils in their English Language sentence construction with and without the use of the WPS Pyramid strategy.

\section{Findings}

The findings on the common mistakes made by the pupils' in their sentence construction had been simplified in the tables below:

Table 4.0 Common Mistakes in pre-writing task

\begin{tabular}{cl}
\hline \multicolumn{1}{c}{ Theme } & \multicolumn{1}{c}{ Item } \\
\hline $\begin{array}{c}\text { Sentence division, fragmented and } \\
\text { clipped sentences and run-ons }\end{array}$ & $\begin{array}{l}\text { RJ - Prize who can get number one in } \\
\text { scrabble competition who can get first } \\
\text { prize. } \\
\text { UT - Pupil performed play scrabble an } \\
\text { need have was they. }\end{array}$ \\
\hline & AA - Many pupils performed the \\
& vocabulary as they does. \\
& EO - *Amira family was very happy \\
& because *Amira have the winner. \\
& FL - Last week, my school was held \\
& Scrabble Compettion (Competition). \\
& HB - We would announced in my school. \\
& UT - We bed winner in after bike to \\
& school someting (something) homework. \\
\hline Incorrect word forms & AA - Winner in this Screbble (Scrabble) \\
& Competition done announced. \\
& EO - The activity was Scrabble competion \\
(competition) because many children not
\end{tabular}




\begin{tabular}{|c|c|}
\hline & $\begin{array}{l}\text { clever. } \\
\text { FL - My school was perfomed } \\
\text { (performed) a very best. } \\
\text { HB - The last day, my school held the } \\
\text { Scrabble competition. } \\
\text { RJ - Prize who can get number one in } \\
\text { scrabble competition who can get first } \\
\text { prize. } \\
\text { UT - Pupil need reed (read) vocabulary } \\
\text { from side to something. }\end{array}$ \\
\hline $\begin{array}{l}\text { Incomplete or incorrect subordinate } \\
\text { clause structure }\end{array}$ & $\begin{array}{l}\text { EO - We need read widely because we } \\
\text { can doen (doing) the sentences. } \\
\text { HB - My school was performed because } \\
\text { tomorrow we held scrabble competition. } \\
\text { RJ - Prize who can get number one in } \\
\text { scrabble competition who can get first } \\
\text { prize. } \\
\text { UT - We pround (proud) because we } \\
\text { hitting a plane making in school. }\end{array}$ \\
\hline $\begin{array}{l}\text { Incoherence conjunctions and } \\
\text { demonstrative pronouns markers }\end{array}$ & $\begin{array}{l}\text { AA - Winner in this Screbble (Scrabble) } \\
\text { Competition done announced. } \\
\text { EO - We need doen (doing) the } \\
\text { vocabulary with suitable because can } \\
\text { give many marks. } \\
\text { FL - My teacher was choose suitable } \\
\text { place. } \\
\text { HB - Many vocabulary that prepared on } \\
\text { the table. }\end{array}$ \\
\hline Singular and plural nouns and pronouns & $\begin{array}{l}\text { AA - Many pupils perfomed (performed) } \\
\text { the vocabulary as they does. } \\
\text { FL - Chair, table and scrabble was } \\
\text { prepared. } \\
\text { RJ - Last Monday, school, I held Scrabble } \\
\text { competition in School SK M*****. }\end{array}$ \\
\hline Missing or incorrect prepositions & $\begin{array}{l}\text { RJ - School who winner namely school SK } \\
\mathrm{M}^{* * * * *} \text { intensely proud because school } \\
\text { they winner. } \\
\text { UT - Pupil a read widely other to their } \\
\text { information. }\end{array}$ \\
\hline Missing or incorrect articles & $\begin{array}{l}\text { FL - We would build vocabulary when we } \\
\text { play the scrabble. } \\
\text { HB - We would play the scrabble } \\
\text { competition today. }\end{array}$ \\
\hline
\end{tabular}


RJ - Prize who can get number one in scrabble competition who can get (missing: the) first prize.

UT - We happy because we doing wathing to the watering in (missing: the) school.

Table 5.0 Common Mistakes in post-writing task

\begin{tabular}{|c|c|}
\hline Theme & Item \\
\hline $\begin{array}{l}\text { Sentence division, fragmented and } \\
\text { clipped sentences and run-ons }\end{array}$ & $\begin{array}{l}\text { RJ - My school held scrabble } \\
\text { competition. Last week in Dewan Sri } \\
\mathrm{T}^{* * * * * * * *} \text {. }\end{array}$ \\
\hline Verb tenses and aspects, verb phrases & $\begin{array}{l}\text { AA - The participants will performed } \\
\text { vocabulary in hall./Winner will } \\
\text { announdced (announce) after the } \\
\text { competition. } \\
\text { EO - The participants was performed in } \\
\text { the steech (stage) goodly./The } \\
\text { participants gived the first prize current } \\
\text { receive the prize in the steech (stage). } \\
\text { FL - The participant will performed talent } \\
\text { very well in hall. } \\
\text { HB - The participants will performed in } \\
\text { the steech (stage). } \\
\text { UT - The (They) would got a lot of } \\
\text { vocabulary through reading./Pupils will } \\
\text { perfomed (performed) playing scrabble } \\
\text { in Dewan Sri T*******. }\end{array}$ \\
\hline Incorrect word forms & $\begin{array}{l}\text { AA - Then, the first prize is bag and books } \\
\text { when we follow this competition. } \\
\text { FL - The winner of compettion } \\
\text { (competition) is my school because my } \\
\text { school attemp (attempt). } \\
\text { HB - My school get the first prize for } \\
\text { scrabble competition at the last week. } \\
\text { UT - If pupils earn to win playing scrabble } \\
\text { they will earn firs (first) prize. }\end{array}$ \\
\hline $\begin{array}{l}\text { Incomplete or incorrect subordinate } \\
\text { clause structure }\end{array}$ & $\begin{array}{l}\text { AA - Scrabble set, tables and chairs were } \\
\text { prepared one day before the } \\
\text { competition in the hall nicely by my } \\
\text { school. } \\
\text { FL - The winner was announced by my } \\
\text { headmaster school whennever }\end{array}$ \\
\hline
\end{tabular}




\begin{tabular}{cl}
\hline & (whenever) the competition finish. \\
& HB - By my school for scrable set, tables \\
and chair were prepared one day before & \\
in hall and nicely. & \\
\hline Incoherence conjunctions and & HB - They would get a lot of vocabulary \\
femonstrative pronouns markers & for through reading. \\
\hline \multirow{3}{*}{ Singular and plural nouns and pronouns } & EO - The participants was performed in \\
& the steech (stage) goodly. \\
& HB - We pround (proud) because the \\
& scrabble competition very interesting for \\
& we at the school. \\
\hline Missing or incorrect prepositions & EO - My friend was winner inside the \\
& scrabble competition because my friend \\
& can doen (doing) a vocabulary. \\
& HB - The participants will performed in \\
& the steech (stage). \\
& UT - Teacher will jotted winner year this. \\
\hline AA - The participants will performed \\
vocabulary in (missing - the) hall. \\
FL - The first prize was prepared by my \\
school in (missing - the) hall. \\
HB - The participants needed to read \\
widely on english (English) books in \\
(missing - the) library or at home. \\
UT - Scrabble competition announced by \\
(missing - the) teacher. \\
\hline
\end{tabular}

\section{Discussion}

The pupils' pre and post-writing responses were analyzed through coding and categorization. The results or findings had shown that they did most of the common mistakes mentioned earlier. The following discussion is organized into the following themes:

\section{- Sentence division, fragmented and clipped sentences and run-ons}

As shown in Table 4.0, 2 out of 6 pupils were found to be having trouble to write sentences with complete meaning or information. These 2 pupils were the least performing pupils in the subject. Hence, they were unable to construct meaningful English Language sentences correctly. In Table 5.0, the same mistake was repeated but the number of pupils decreased. In the table above, the pupil was unable to connect his sentences appropriately.

\section{- Verb tenses and aspects, verb phrases}

Most of the pupils, with a number of 5 pupils, were unable to construct sentences using verbs correctly as shown in Table 4.0. Some of them were unable to use correct verbs in their English Language writing. This had shown that the pupils were having limited or poor knowledge on the verbs 
INTERNATIONAL JOURNAL OF ACADEMIC RESEARCH IN BUSINESS AND SOCIAL SCIENCES

Vol. 10, No. 2, Feb, 2020, E-ISSN: 2222-6990 ¿ 2020 HRMARS

vocabulary. In Table 5.0, it was found that the pupils were still repeating the same mistake and still constructing sentences with poor verb choices.

\section{- Incorrect word forms}

Similar to the previous common mistake, all 6 pupils were found to be lacking of word or vocabulary knowledge in the English Language as the sentences they had written were observed as direct translation of Bahasa Melayu into English Language as shown in Table 4.0. However, the pupils had shown some improvement in their word forms when they were able to apply better choice of words to present their ideas in their post-writing task as shown in Table 5.0.

\section{- Incomplete or incorrect subordinate clause structure}

In their pre-writing task, as shown in Table 4.0, the pupils were unable to connect their clauses correctly. Their sentences were observed to be incoherent as the clauses did not compliment each other. Hence, the meaning which they tried to convey could not be identified. However, in their postwriting task, there was an increased writing ability among the pupils. Although the sentences were not grammatically correct written, but the meaning which the pupils tried to convey could be identified easily as shown in Table 5.0.

\section{- Incoherence conjunctions and demonstrative pronouns markers}

The pupils performed poorly in constructing sentences using conjunctions and pronouns in their prewriting task. Most of them were unable to use correct form of conjunctions and pronouns. In postwriting task, this mistake decreased as most of the pupils were able to use conjunctions and pronouns better.

\section{- Singular and plural nouns or pronouns}

As shown in Table 4.0, 2 pupils were using incorrect form of singular and plural nouns in their sentences. 1 pupil was using incorrect pronoun in his writing. In Table 5.0, the pupils were able to construct better sentences although they were still lacking in their usage of singular and plural nouns or pronouns.

\section{- Missing or incorrect prepositions}

In the pre-writing task, the said least performing pupils were unable to construct sentences using appropriate prepositions. In addition, the meaning which they tried to convey was incomprehensible. In the post-writing task, one of them and another 2 pupils were unable to write sentences using appropriate prepositions although their sentences conveyed meaning as compared to what had been written in the pre-writing task.

\section{- Missing or incorrect articles}

In Table 4.0, some of the pupils were using incorrect article and some of them were constructing sentences without appropriate article. They were not familiar with the use of article in the English Language sentence construction as in Bahasa Melayu, they do not insert similar form of article to show the nouns. In Table 5.0, although the pupils had improvement in their sentence construction, they were still unable to use articles in their writing. 
Out of the 10 common mistakes mentioned earlier, the pupils did 8 of them, both in their pre and post-writing tasks. The other two common mistakes mentioned were subject-verb-agreement and incorrect modal verbs. In this research, the pupils were found to be able to construct sentences which adhered to the subject-verb-agreement. All of them were able to master this writing technique. However, modal verbs were not presented in the tasks. It could be said that the pupils did not use modal verbs at all in their English Language sentence construction. In this research, the WPS Pyramid strategy could be used to lessen the mistakes, but it still depend on the pupils' learning styles as well as the pupils' knowledge in the English Language vocabulary and grammar.

\section{Conclusion}

As the study relates closely to the teaching of sentence construction, hence it has high possibility in assisting English Language teachers in their teaching of sentence construction especially among pupils with low proficiency level in the English Language. As this study is based on Constructivism Theory, pupils are seen to have the opportunity to learn sentence construction by learning it in a more meaningful way. Therefore, English Language teachers will be able to conduct more effective and motivating lessons or teaching activities for the ESL pupils who are struggling to perform sentence construction. Pupils begin to solve their own learning difficulties based on what they had learnt to do during the introduction and implementation of WPS Pyramid strategy as they are becoming interested and are able to construct better sentences. This statement supports the idea stated by Pragasam et. al. (2018) who stated that Constructivism Theory enables pupils to become better at problem solving once they started to acknowledge their own learning. Apart from that, as this study is also based on Multiple Intelligences, it indicates that the study focuses on the pupils' learning development throughout the study. Pupils with different learning preferences are given equal opportunities to experience effective learning in the same situation. The study highlights student-centred approach where pupils are expected to perform the learning strategy on their own following teacher's explanation and guidance.

The findings of the study suggested that Ministry of Education (MOE) in the country to develop and plan relevant courses for the teachers. This study can be introduced as one of the writing strategies in ESL courses to assist teachers to deal with low performing ESL pupils in their schools. This course can be conducted in Pejabat Pendidikan Daerah (PPD). There is a group of academic development officers in every PPD whose specialty is to coach and guide teachers to develop and improve their teaching and learning pedagogy in schools. WPS Pyramid strategy can be introduced as a remedial activity in the teaching and learning of English Language conducted by teachers in school. As this study was conducted in a low enrolment school, it is recommended that future study to be conducted to a bigger group in order to gain findings which can be generalized to all primary 6 pupils in the country or district. Also, it is recommended that future study to include more schools for a better generalization purpose.

\section{References}

Ahn, H. (201 2). Teaching writing skills based on a genre approach to L2 primary school students: An action research. English Language Teaching, 5(2), 2-16.

Arshad, A. S., \& Hawanum, H. (2017). Teaching grammar and what student errors in the use of the English auxiliary 'be' can tell us. The English Teacher, XXXIX, 164-178. 
INTERNATIONAL JOURNAL OF ACADEMIC RESEARCH IN BUSINESS AND SOCIAL SCIENCES Vol. 10, No. 2, Feb, 2020, E-ISSN: 2222-6990 @ 2020 HRMARS

Braun, V., \& Clarke, V. (2006). Using thematic analysis in psychology. Qualitative Research in Psychology, 3(2), 77-101.

Bree, R., \& Gallagher, G. (2016). Using microsoft excel to code and thematically analyze qualitative data: A simple, cost effective approach. All Ireland Journal of Teaching and Learning in Higher Education, 2(8), 2811-2824.

Bowen, G. A. (2009). Document analysis as a qualitative research method. Qualitative Research Journal, 9(2), 27-40.

Dg Nursazwani, D., Wardatul, A. D., \& Asmaa, A. (2018). Exploring the VAW method of writing among ESL primary pupils: Conceptual Paper. International Journal of Applied Linguistics \& English Literature, 7(4), 248-252.

Etikan, I., Sulaiman, A. M., \& Rukayya, S. A. (2016). Comparison of convenience sampling and purposive sampling. American Journal of Theoretical and Applied Statistics, 1(5), 1-4.

Faidah, R. T., Fauziati, E., \& Suparno. (2019). Teachers beliefs on multiple intelligence based English teaching for young learners. Exposure Journal, 8(1), 60-72.

Gardner, H., \& Hatch, T. (1989). Educational implications of the theory of multiple intelligences. Educational Researcher, 8(18), 4-10.

Hinkel, E. (2010). What research on second language writing tells us and what it doesn't. Research in Second Language Processes and Development, 32, 523-537.

Ilyana, J., Paramasivam, S., Salina, H., \& Roslina, A. B. (2015). The consistency between writing selfefficacy and writing performance. Journal of Language Teaching and Research, 6(3), 545-552.

Lau, J. L., Anthony, E., \& Melor, M. Y. (2019). Teaching present continuous sentence with rainbow tower in rural primary school. International Journal of Academic Research in Business and Social Sciences, 9(2), 538-544.

Kementerian Pendidikan Malaysia. (2015). Dokumen Standard Kualiti Pendidikan: Bahasa Inggeris Tahun 4.

Maros, M., Tan, K. H., \& Khazriyati, S. (2007). Interference in learning English: Grammatical errors in English essay writing among rural Malay secondary school students in Malaysia. Jurnal Elektronik Fakulti Sains Sosial dan Kemanusiaan, 2(2), 1-15.

Melor, M. Y., Tan, M. M., \& Asyraf, M. K. (2019). Writing essays made easy with instawrite. International Journal of Academic Research in Business \& Social Sciences, 9(1), 332-342.

Noor, M. A. A., \& Nurahimah, M. Y. (2015). Using portfolio to assess rural young learners' writing skills in English Language classroom. The Malaysian Online Journal of Educational Science, 3(4), 4653.

Nooreiny, M., Hamidah, Y., \& Ken, L. L. (2011). Role of teacher, peer and teacher-peer feedback in enhancing ESL students' writing. World Applied Sciences Journal 15 (Innovation and Pedagogy for Lifelong Learning), 29-35.

Pragasam, J. A., Singh, C. K. S., Singh, T. S. M., Azmi, N. M., Hasimah, J., Maria, S. A., Noraini, Z., \& Farah, N. M. K. (2018). The use of task-based learning (TBL) to improve form four students' performance in narrative writing. International of Academic Research in Progressive Education and Development, 7(3), 48-59.

Rudd, M. (2019). Introducing constructivism to young learners: Analysing the impact on English Language performance. Journal of Culture, Society and Development, 46, 51-58.

Silva, R. D. (2014). Writing strategy instruction: Its impact on writing in a second language for 
INTERNATIONAL JOURNAL OF ACADEMIC RESEARCH IN BUSINESS AND SOCIAL SCIENCES Vol. 10, No. 2, Feb, 2020, E-ISSN: 2222-6990 @ 2020 HRMARS academic purposes. Language Teaching Research, 1-24. 